\title{
Prolonged Follow-up and CSF Antibody Titers in a Patient With Anti-NMDA Receptor Encephalitis
}

Figure

Serum and CSF antibodies

A

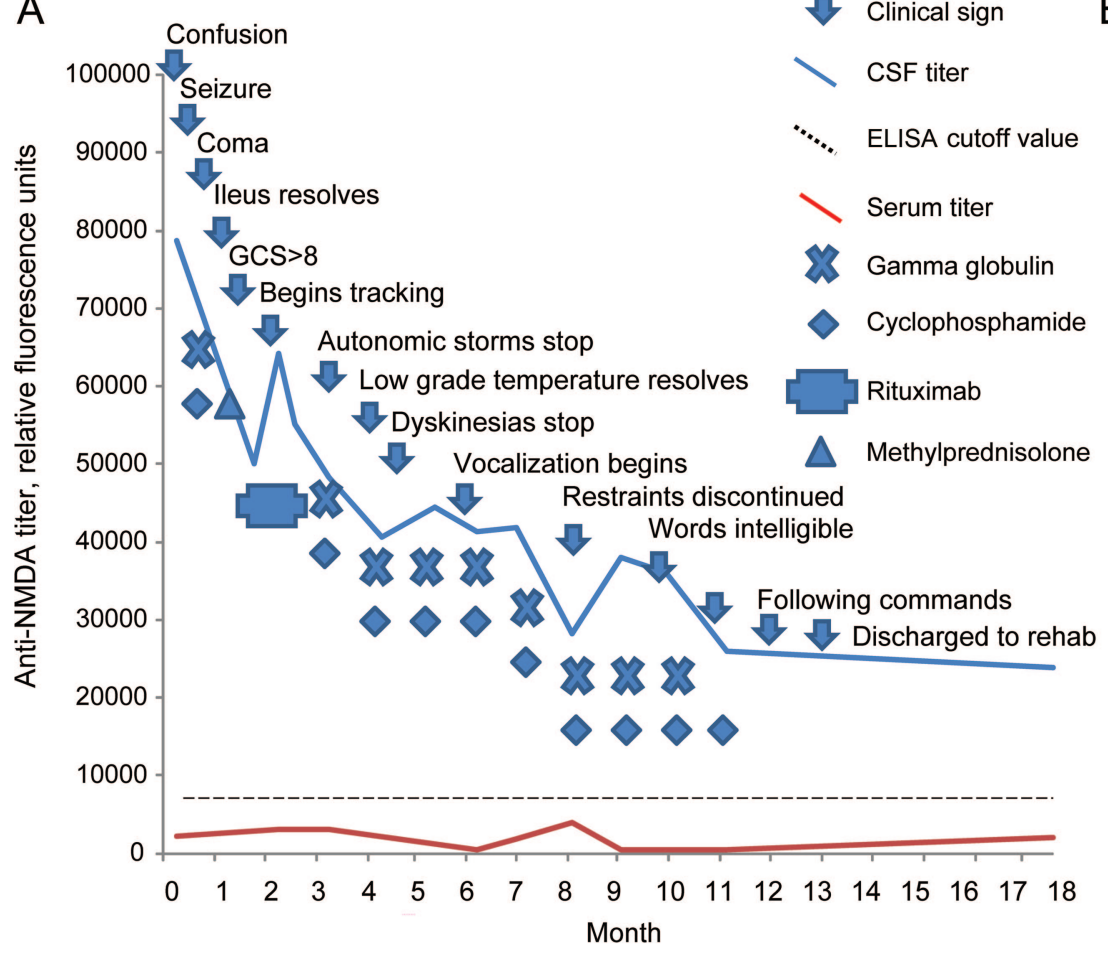

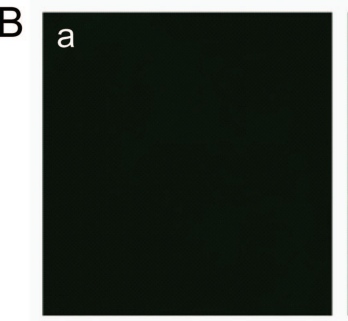
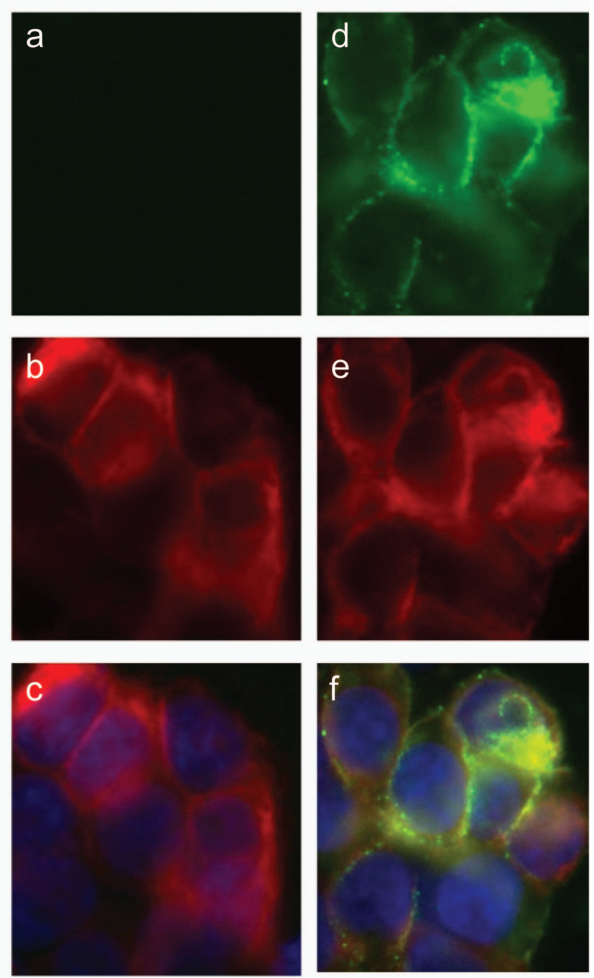

(A) Time course of clinical features and levels of antibodies in CSF and serum. Improvement of symptoms correlated with the levels of NMDA receptor (NMDAR) antibodies in CSF (blue line). The levels of antibodies in serum (red line) were below the previously established cutoff value of ELISA (dotted line). ${ }^{1}$ Serum and CSF were compared after normalizing the total amount of immunoglobulin G (4 mg/100 mL). GCS = Glasgow Coma Scale. (B) Comparison of reactivity of initial serum and CSF samples (obtained at patient's hospital admission) with cells transfected with NR1/NR2 subunits of the NMDAR. Panels a-c show reactivity of patient's serum diluted at 1:40 (a), a commercial antibody against NR1 at 1:1,000 (b), and the overlay of stainings with labeling of the nuclei with DAPI (c). Panels $d-f$ show reactivity of patient's CSF diluted at 1:40 (d), a commercial antibody against NR1 at 1:1,000 (e), and the overlay of stainings with labeling of the nuclei with DAPI (f). Note that antibodies are visible in CSF but not in serum. Similar studies were performed with serially obtained serum and CSF samples (time points shown in A), all showing antibodies in CSF but not serum.

A nti-NMDA receptor (NMDAR) encephalitis is a form of autoimmune encephalitis characterized by flulike prodromal symptoms, psychosis, memory problems, seizures, abnormal movements, and autonomic disturbances. We report a man with prolonged follow-up of symptoms and antibody titers during a 1-year hospital admission.

CASE REPORT An 18-year-old man was admitted to an outside hospital for hallucinations, jerky limb movements, and encephalopathy. Twelve days after admission, NMDAR antibodies were detected in the CSF. He was started on IV immunoglobulin (IVIg), methylprednisolone, propofol, phenytoin, and levetiracetam, and transferred to our center.

On arrival, he was febrile, tachycardic, and ventilator-dependent. His pupils were reactive, but after sedation was weaned, he could not fix and follow, and he did not blink to threat. He had rhythmic orofacial movements characterized by chewing, blinking, and tongue thrusting. Muscle tone and reflexes were increased throughout, and he did not respond to painful stimulation. 
The patient was stuporous for nearly 12 months. He had complex movements of the face and slow rhythmic motions with the arms, hands, and fingers, as if conducting an orchestra. For 4 months, he had periods of sinus tachycardia, tachypnea, and hypertension that lasted for 10-20 minutes and partially responded to IV opiates, $\beta$-blockers, benzodiazepines, or hydration. EEG revealed a background of generalized slow and disorganized activity, but also intermittent low-voltage gamma that was phaselocked to underlying delta activity. There was no EEG correlate with the movements or autonomic dysfunction, however, epileptic activity was noted intermittently in the frontal cortex and would occasionally secondarily generalize to clinically apparent tonic-clonic seizures. The presence of a systemic tumor was excluded with CT of the chest, abdomen, and pelvis and testicular ultrasound.

Initial treatments with IVIg and methylprednisolone were not effective. Subsequent immunotherapy included rituximab $375 \mathrm{mg} / \mathrm{m}^{2}$ once a week for 6 weeks, and monthly cycles of cyclophosphamide, $750 \mathrm{mg} / \mathrm{m}^{2}$, and IVIg $2 \mathrm{~g} / \mathrm{kg}$. Antibody levels in serum and CSF were examined monthly before each cycle of cyclophosphamide and IVIg using 2 reported techniques. ${ }^{1}$ Serum antibodies were consistently negative but CSF antibodies remained detectable during the patient's stay in the hospital and the levels paralleled the course of the disease (figure).

After 11 months of inpatient treatment, repeat tumor screening was negative. After 12 months, the patient was able to speak, laugh, and intermittently follow one-step commands, and he was discharged to a rehabilitation center without further immunotherapy.

Repeat MRI 14 months after symptom presentation showed mild general brain atrophy. After 18 months of illness, he was able to respond "Europe" when queried regarding a desired vacation, and would scream "cheeseburger" when asked about food. He had difficulty perceiving images in their entirety, consistent with simultanagnosia. The last seizure occurred 18 months after symptom presentation. Anticonvulsants were weaned slowly, from 7 when he was admitted to no medications 21 months later. Two years after symptom onset, the patient speaks fluently, has a good sense of humor, can read and answer questions correctly, follows embedded commands, has no apraxia and no neglect, and is strong throughout. He is able to play card and video games with others. Simultanagnosia persists, and he occasionally makes unusual noises and speaks to himself. Although finger and knee contractures limit his dexterity and mobility, he is able to walk with minimal assistance; physical and occupational therapy continue.
Three Important Features in Patients With Anti-NMDAR Encephalitis

- Patients may have prolonged clinical course.

- CSF antibodies correlate with clinical outcome.

- Consider aggressive immunotherapy.

DISCUSSION This case illustrates 3 important features in patients with anti-NMDAR encephalitis: 1) patients may have a very prolonged clinical course ${ }^{2}$; 2) the levels of CSF antibodies correlate better with clinical outcome than serum antibody titers ${ }^{1,3}$; and 3) aggressive immunotherapy should be considered when there is no clinical response to first-line immunotherapy (corticosteroids, IVIg, or plasma exchange). ${ }^{4,5}$ A recent review of 105 patients showed that while $80 \%$ of patients with a tumor (mostly teratomas) had substantial improvement after tumor removal and first-line immunotherapy, only $48 \%$ of those without a tumor had a similar degree of improvement after first-line immunotherapy (Fisher exact test, $p=0.001$ ) and more frequently required second-line immunotherapy (rituximab, cyclophosphamide). ${ }^{6}$ With this approach, the final outcome regarding substantial improvement was similar in patients with or without tumor $(84 \%$ vs $71 \%, p=$ 0.16). Clinical experience indicates that chronic use of antiepileptic drugs is not needed in most patients who have had substantial recovery, as in our patient. Given that $20 \%$ of patients without tumor have neurologic relapses, future studies should assess the role of chronic, steroid-sparing immunosuppressants. Mycophenolate mofetil was offered to our patient but the family preferred a close follow-up.

\section{Eric S. Frechette, MD, PhD, Lei Zhou, MD, Steven L. Galetta, MD, Lei Chen, MD, PhD, Josep Dalmau, $M D, P h D$}

From the Department of Neurology, University of Pennsylvania School of Medicine, Philadelphia.

Disclosure: Dr. Frechette and Dr. Zhou report no disclosures. Dr. Galetta serves on the editorial boards of $\mathrm{Neurology}{ }^{\circledR}$ and the Journal of Neuro-ophthalmology; has received speaker honoraria from Biogen Idec and Teva Pharmaceutical Industries Ltd.; has served as a consultant for Medtronic, Inc., Biogen Idec, and Teva Pharmaceutical Industries Ltd.; and serves on the speakers' bureau for Biogen Idec. Dr. Chen reports no disclosures. $D r$. Dalmau has received royalties from a patent re: Ma2 autoantibody test and has patents pending re: NMDA and GABAB receptor autoantibody tests (license fee payments received from EUROIMMUN AG) and receives research support from funding from EUROIMMUN AG and the NIH/NCI

Received September 14, 2010. Accepted in final form December 16, 2010. Address correspondence and reprint requests to Dr. Josep Dalmau, Department of Neurology, 3 W. Gates (Division of Neurooncology), University of Pennsylvania, 3400 Spruce Street, Philadelphia,PA 19104; josep.dalmau@uphs.upenn.edu 


\section{REFERENCES}

1. Dalmau J, Gleichman AJ, Hughes EG, et al. Anti-NMDAreceptor encephalitis: case series and analysis of the effects of antibodies. Lancet Neurol 2008;7:1091-1098.

2. Iizuka T, Sakai F, Ide T, et al. Anti-NMDA receptor encephalitis in Japan: long-term outcome without tumor removal. Neurology 2008;70:504-511.

3. Prüss $\mathrm{H}$, Dalmau J, Harms L, et al. Retrospective analysis of NMDA receptor antibodies in encephalitis of unknown origin. Neurology 2010;75:1735-1739.
4. Ishiura $\mathrm{H}$, Matsuda $\mathrm{S}$, Higashihara $\mathrm{M}$, et al. Response of anti-NMDA receptor encephalitis without tumor to immunotherapy including rituximab. Neurology 2008;71: 1921-1923.

5. Wong-Kisiel LC, Ji T, Renaud DL, et al. Response to immunotherapy in a 20-month-old boy with anti-NMDA receptor encephalitis. Neurology 2010;74:1550-1551.

6. Dalmau J, Lancaster E, Martinez-Hernandez E, et al. Experience and Investigations on anti-NMDA receptor encephalitis. Lancet Neurol 2011;10:63-74. 


\section{Neurology}

\section{Prolonged Follow-up and CSF Antibody Titers in a Patient With Anti-NMDA Receptor Encephalitis}

Eric S. Frechette, Lei Zhou, Steven L. Galetta, et al. Neurology 2011;76;S64-S66

DOI 10.1212/WNL.0b013e31820c34de

\section{This information is current as of February 14, 2011}

\section{Updated Information \& Services}

References

Citations

Subspecialty Collections

Permissions \& Licensing

Reprints including high resolution figures, can be found at: http://n.neurology.org/content/76/7_Supplement_2/S64.full

This article cites 6 articles, 4 of which you can access for free at: http://n.neurology.org/content/76/7_Supplement_2/S64.full\#ref-list-1

This article has been cited by 2 HighWire-hosted articles: http://n.neurology.org/content/76/7_Supplement_2/S64.full\#\#otherartic les

This article, along with others on similar topics, appears in the following collection(s):

All Epilepsy/Seizures

http://n.neurology.org/cgi/collection/all_epilepsy_seizures All Immunology

http://n.neurology.org/cgi/collection/all_immunology

All Movement Disorders

http://n.neurology.org/cgi/collection/all_movement_disorders

Cerebrospinal Fluid

http://n.neurology.org/cgi/collection/cerebrospinal_fluid

Paraneoplastic syndrome

http://n.neurology.org/cgi/collection/paraneoplastic_syndrome

Information about reproducing this article in parts (figures,tables) or in its entirety can be found online at:

http://www.neurology.org/about/about_the_journal\#permissions

Information about ordering reprints can be found online:

http://n.neurology.org/subscribers/advertise

Neurology ${ }^{\circledR}$ is the official journal of the American Academy of Neurology. Published continuously since 1951, it is now a weekly with 48 issues per year. Copyright Copyright $@ 2011$ by AAN Enterprises, Inc.. All rights reserved. Print ISSN: 0028-3878. Online ISSN: 1526-632X.

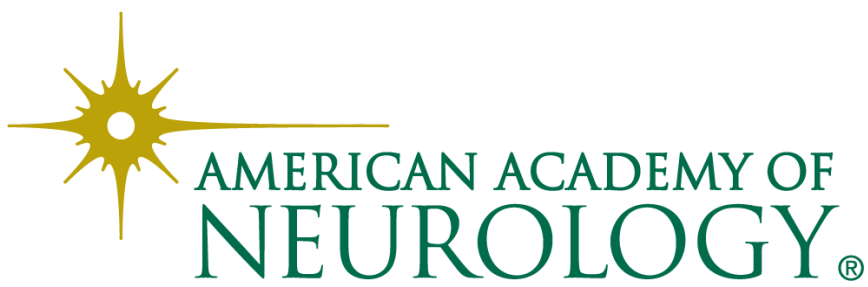

